\section{Case Reports in Neurology}

Case Rep Neurol 2021;13:398-404

DOI: 10.1159/000513977
Published online: June 17, 2021

(C) 2021 The Author(s)

Published by S. Karger AG, Basel OPEN

www.karger.com/crn

This article is licensed under the Creative Commons Attribution-NonCommercial 4.0 International License (CC BY-NC) (http://www.karger.com/Services/OpenAccessLicense). Usage and distribution for commercial purposes requires written permission.

\title{
Fatal Case of COVID-19 Pneumonia Associated with Acute Myelopathy
}

\author{
Hayder K. Hassoun ${ }^{a, b} \quad$ Mohammed R. Radeef ${ }^{a} \quad$ Zahra Aljid $^{a}$ \\ Zuhair Allebban ${ }^{c}$ \\ aFaculty of Medicine, Kufa University, Middle Euphrates Neurosciences Center, Al-Najaf \\ Al-Ashraf, Iraq; ${ }^{\text {b}}$ AlSakuni Neuroscience Center, Al-Najaf Al-Ashraf, Iraq; ${ }^{c}$ Middle \\ Euphrates Unit for Cancer Research, Faculty of Medicine, University of Kufa, Al-Najaf Al- \\ Ashraf, Iraq
}

\section{Keywords}

COVID-19 - Myelitis · Neurological manifestations · SARS virus

\begin{abstract}
In December 2019, a novel coronavirus outbreak with multiple system involvement started initially in Wuhan City, Hubei Province of China. Coronavirus disease 2019 (COVID-19) infection is a systemic disorder typically presenting with fever, fatigue, and upper and lower respiratory symptoms, although neurological manifestations are increasingly reported, but pathological mechanisms have yet to be established. The symptoms of infection with COVID-19 are dependent on the patient's age and underlying medical illness, and on the condition of the immune system. Neurotropic and neuroinvasive capabilities of coronaviruses have been described in humans. We herein report a patient infected with COVID-19 who developed pneumonia associated with acute progressive myelopathy. Neurological examination revealed progressive flaccid areflexic paralysis of lower limbs over 3 days with retention of urine and sensory level at 10th spinal thoracic segment (T10). The patient had a positive nasopharyngeal swab for COVID-19 at the onset of the neurological symptoms. This case of acute progressive myelopathy adds further evidence of the complications of severe COVID-19 infection, and we are dealing with a virus of unpredictable behavior. Since this virus neurotropism is not clear yet, further investigations should be conducted on the mechanism of possible neurological infection in patients with COVID-19.




\section{Case Reports in Neurology}

Case Rep Neurol 2021;13:398-404

DOI: $10.1159 / 000513977$

(c) 2021 The Author(s). Published by S. Karger AG, Basel www.karger.com/crn

Hassoun et al:: COVID-19 and Acute Myelopathy

\section{Background}

In December 2019, the first case of pneumonia with unknown etiology was reported in Wuhan city, China [1]. The identified pathogen was a novel Severe Acute Respiratory Syndrome Coronavirus 2 (SARS-CoV-2), which would be later known as COVID-19. COVID-19 spread to Europe, North America, and Asia within a short time [2,3] and caused significant public fear and stressed the healthcare systems all over the world. Although most have mild symptoms, such as fever, headache, cough, dyspnea, myalgia, and anosmia, some developed acute respiratory distress syndrome about a week into the illness, which can result in death $[2,4]$ In a recent COVID 19 study, neurological symptoms and manifestations were reported in $37 \%$ (50\% in severe infection) of 214 COVID-19 patients reported from Wuhan, including nonspecific symptoms of headache and dizziness ( $20 \%$ of cases), altered mentation ( $15 \%$ of severe infection), severe muscle ache and myalgia ( $20 \%$ of cases), and loss of taste and smell sense, which may give initial clue to COVID-19 infection [2]. Other neurological complications were reported in association, including viral meningitis, encephalitis, postinfectious acute disseminated encephalomyelitis, postinfectious brainstem encephalitis, acute necrotizing encephalitis, Guillain-Barré syndrome (GBS), myositis, and cerebrovascular accident [4-7]. Coronaviruses in general are considered respiratory viruses, but recent reports have also shown that they are able to infect the central nervous system (CNS) and cause neurological disorders [6]. It has been reported that coronavirus infects the nasal mucous membrane and enters the CNS through the olfactory bulb, blood circulation, ACE2 in brainstem, immune injury, and neuronal pathways, resulting in neurological disorders and also causing inflammation and demyelination. In this report, we present a fatal COVID-19 infection associated with acute progressive myelopathy which is rarely reported in COVID-19 infections.

\section{Case Report}

The patient was a 77-year-old Iraqi male with a history of hypertension, diabetes, and ischemic heart disease who was on captopril $25 \mathrm{mg}$ tablet twice daily for hypertension, metformin $500 \mathrm{mg}$ tablet twice daily for diabetes, and aspirin $100 \mathrm{mg}$ tablet once daily with atorvastatin $20 \mathrm{mg}$ tablet. He was admitted to the emergency department at Kufa University teaching hospital in the city of Al-Najaf Al-Ashraf in Iraq. He presented with progressive weakness in his lower limbs for 3 days, retention of urine, loss of all sensations in the lower limbs up to umbilicus level. His presentation was preceded by 4 days of febrile illness but no shortness of breath or cough. General examination was good with full consciousness (wakeful and alert) and normal vital signs. Apart from low-grade fever $\left(38^{\circ} \mathrm{C}\right)$, there was no dyspnea or tachypnea; chest auscultation showed fine crackles and normal S1 and S2 heart sounds. The abdomen was soft with palpable distended bladder. Neurological examination revealed normal higher cerebral function including speech and intact cranial nerves. Upper limb examination showed normal strength (power grade $5 / 5$ ); reflexes were +2 with normal sensory examination. Lower limb examination revealed flaccid paralysis (power grade $0 / 5$ ) and hypotonia, and reflexes were grade 0 with initially bilateral mute planter reflex, then after 2 days it became extensor. Sensory level was at T10 (umbilicus level), and below it, all modality of sensations (sensations, pain, temperature, touch, vibration, and joint position) had been lost with retention of urine. Initial laboratory results revealed elevated WBC count with lymphopenia and elevated renal indices. Chest CT showed typical feature of COVID-19 (Fig. 1,2) with typical

\section{Karger'=}




\section{Case Reports in Neurology}

Case Rep Neurol 2021;13:398-404

DOI: $10.1159 / 000513977$

(c) 2021 The Author(s). Published by S. Karger AG, Basel www.karger.com/crn

Hassoun et al.: COVID-19 and Acute Myelopathy

finding of multiple peripheral ground-glass pulmonary opacities, more so in upper lobes and associated with fine reticulation with interlobar septal thickening. Cervical dorsal area MRI (Fig. 3) and lumbosacral spine (Fig. 4, 5) were done in the emergency unit without the use of contrast (because of renal impairment) revealing normal degenerative change without any obvious lesion mentioned. Other viral and bacterial causes of infectious myelitis were excluded by PCR screening and serology tests. PCR test was used for cytomegalovirus, EpsteinBarr virus, herpes simplex virus type 1 (HSV-1), HSV-2 and serology test for hepatitis C virus, Mycoplasma pneumoniae, and Brucella; all tests were negative. The interferon gamma release assays test using Quanti FERON ${ }^{\circledR}$-TB Gold In-Tube test was negative for Mycobacterium tuberculosis. The patient was immediately isolated and kept on $1 \mathrm{~g}$ methylprednisolone i.v. solution (Solu-Medrol-Pfizer) pulse therapy with control of hyperglycemia by insulin therapy, ceftriaxone (Mesporin-Mepha) $1 \mathrm{~g}$ i.v. infusion twice daily, and azithromycin capsule (AziOnce/Jamjoom Pharma) $250 \mathrm{mg}$ two capsules once daily. He was referred to the local hospital designated to care for COVID-19 on the second day after a positive real-time reverse transcription polymerase chain reaction RT-PCR test result.

The real-time reverse transcription polymerase chain reaction test for SARS-CoV-2 was completed using a nasopharyngeal swab transported in an M4 viral tube to the hospital central laboratory for analysis. In the following 2 days, the patient's condition progressively deteriorated with shortening of breath, and he was admitted to the intensive care unit and kept on mechanical ventilation where he died 4 days later due to multiorgan failure and septicemia.

\section{Discussion}

The neurological components are obviously not the major focus of COVID-19 infection. It is still early to conclude that the virus is neurotropic, and the neurological complications in our case are possibly an indirect effect of the infection. Previous studies reported that COVID19 patients showed neurological signs such as headache, nausea, and vomiting [8], while one study reported COVID-19 patients with severe symptoms did show acute cerebrovascular disease and impaired consciousness and also suggested a possible neuroinvasion [2].

The reported COVID-19 cases with neurological manifestations tend to occur more frequently in severe infections and in older people with comorbidities, such as diabetes mellitus (DM) and hypertension [5, 9]. It has been reported that SARS-CoV and MERS-CoV coronaviruses were detected in the CSF of a patient with encephalitis and acute respiratory distress syndrome [10], and these viruses along with COVID-19 have ACE-2 receptors on the respiratory epithelial cells, glial cells, neurons, and vascular endothelium $[5,6]$, which may indicate that COVID-19 possibly target and damage the nerve tissues. Myelopathy is rarely reported in association with COVID-19 infection. Three COVID-19 cases of myelitis were published recently, the first case from Wuhan, China, with myelitis associated with COVID-19 [11], the second case from Boston, USA, where the patient presented with respiratory symptoms and then developed acute myelitis 7 days later [12], and the third case was a 32-year-old COVID-19positive male who presented with a 2-day history of flu-like symptoms followed by a sudden onset paraplegia and urinary retention [13].

Our initial diagnosis was GBS, but the presence of sensory level, Babinski signs, and retention of urine make neuropathy (GBS) unlikely, and myelopathy was our provisional diagnosis and most probably inflammatory, as vascular myelopathy is unlikely to present with progression over days with loss of all modality sensation. Lumbosacral and dorsal spine MRI

\section{Karger'=}




\section{Case Reports in Neurology}

\begin{tabular}{l|l}
\hline Case Rep Neurol 2021;13:398-404 \\
\hline DOI: 10.1159/000513977 & $\begin{array}{l}\text { @ 2021 The Author(s). Published by S. Karger AG, Basel } \\
\text { www.karger.com/crn }\end{array}$ \\
\hline
\end{tabular}

Hassoun et al.: COVID-19 and Acute Myelopathy

were unremarkable, which has been reported in transverse myelitis with normal MRI [14]. We recognize that the main limitation was that we could not arrange for CSF examination because of referral of the patient to a hospital that cares for COVID-19 patients, during an extreme circumstance in our hospital at the peak of this pandemic, in addition to rapid deterioration in the patient clinical status. The patient died shortly after the onset of infection with respiratory failure.

COVID-19 may play a role either through direct virus effect that may be confirmed by the isolation of the virus from the cerebrospinal fluid and autopsies of the victims, or indirectly via an abnormal immune or inflammatory reaction due to the cytokine storm [15]. The application of modern technologies, such as genetic sequencing, is warranted as this may determine the direct link between the virus and neuronal manifestations.

\section{Statement of Ethics}

Written informed consent from the patient's next of kin to publish the findings of this case along with the accompanying images was obtained, without revealing the patient's identity. An approval letter from the Institutional Review Board at Kufa University was obtained.

\section{Conflict of Interest Statement}

The authors have no conflicts of interest to declare.

\section{Funding Sources}

No funding was obtained for this study.

\section{Author Contributions}

H.K.H. supervised and performed the clinical evaluation and data collection and revised the final draft of the manuscript; M.R.R. and Z.A. performed the clinical evaluation and data collection and revised the final draft of the manuscript; Zu.A. performed the lab testing, collected the laboratory data, and drafted the manuscript and revised the final draft..

\section{References}

1 Zhou P, Yang XL, Wang XG, Hu B, Zhang L, Zhang W, et al. A pneumonia outbreak associated with a new coronavirus of probable bat origin. Nature. 2020 Mar;579(7798):270-3.

2 Mao L, Jin H, Wang M, Hu Y, Chen S, He Q, et al. Neurologic Manifestations of Hospitalized Patients With Coronavirus Disease 2019 in Wuhan, China. JAMA Neurol. 2020 Jun;77(6):683-90.

3 Coronavirus disease (COVID-19) Pandemic. Geneva: World Health Organization; 2020 Mar. Available from: https://www.who.int/emergencies/diseases/novel-coronavirus-2019.

4 Zhou F, Yu T, Du R, Fan G, Liu Y, Liu Z, et al. Clinical course and risk factors for mortality of adult inpatients with COVID-19 in Wuhan, China: a retrospective cohort study. Lancet. 2020 Mar;395(10229):1054-62.

\section{Karger'=}




\section{Case Reports in Neurology}

\begin{tabular}{l|l}
\hline Case Rep Neurol 2021;13:398-404 \\
\hline DOI: 10.1159/000513977 & $\begin{array}{l}\text { ○ 2021 The Author(s). Published by S. Karger AG, Basel } \\
\text { www.karger.com/crn }\end{array}$ \\
\hline
\end{tabular}

Hassoun et al.: COVID-19 and Acute Myelopathy

5 Khatoon F, Prasad K, Kumar V. Neurological manifestations of COVID-19: available evidences and a new paradigm. J Neurovirol. 2020 Oct;26(5):619-30.

6 Morgello S. Coronaviruses and the central nervous system. J Neurovirol. 2020 Aug;26(4):459-73.

7 Baig AM, Khaleeq A, Ali U, Syeda H. Evidence of the COVID-19 virus targeting the CNS: tissue distribution, host-virus interaction, and proposed neurotropic mechanisms. ACS Chem Neurosci. 2020 Apr;11(7):995-8.

8 Huang C, Wang Y, Li X, Ren L, Zhao J, Hu Y, et al. Clinical features of patients infected with 2019 novel coronavirus in Wuhan, China. Lancet. 2020 Feb;395(10223):497-506.

9 Junior LS, Aquino PL, Rabelo NN, Aquino MA, Silva AC, Mota RD, et al. SARS-CoV-2 and Nervous SystemNeurological Manifestations in Patients With COVID-19: A Systematic Review. J Neurol Res. 2020 Aug;10(4):113-21.

10 Hung EC, Chim SS, Chan PK, Tong YK, Ng EK, Chiu RW, et al. Detection of SARS coronavirus RNA in the cerebrospinal fluid of a patient with severe acute respiratory syndrome. Clin Chem. 2003 Dec;49(12):21089.

11 Zhao K, Huang J, Dai D, Feng Y, Liu L, Nie S. Acute myelitis after SARS-CoV-2 infection: a case report. Medrxiv. 2020 Mar;20035105; doi: https://doi.org/10.1101/2020.03.16.20035105.

12 Sarma D, Bilello LA. A case report of acute transverse myelitis following novel coronavirus infection. Clin Pract Cases Emerg Med. 2020 Aug;4(3):321-3.

13 Munz M, Wessendorf S, Koretsis G, Tewald F, Baegi R, Krämer S, et al. Acute transverse myelitis after COVID19 pneumonia. J Neurol. 2020 Aug;267(8):2196-7.

14 Wong SH, Boggild M, Enevoldson TP, Fletcher NA. Myelopathy but normal MRI: where next? Pract Neurol. 2008 Apr;8(2):90-102.

15 Mehta P, McAuley DF, Brown M, Sanchez E, Tattersall RS, Manson JJ; HLH Across Speciality Collaboration, UK. COVID-19: consider cytokine storm syndromes and immunosuppression. Lancet. 2020 Mar;395(10229):1033-4.

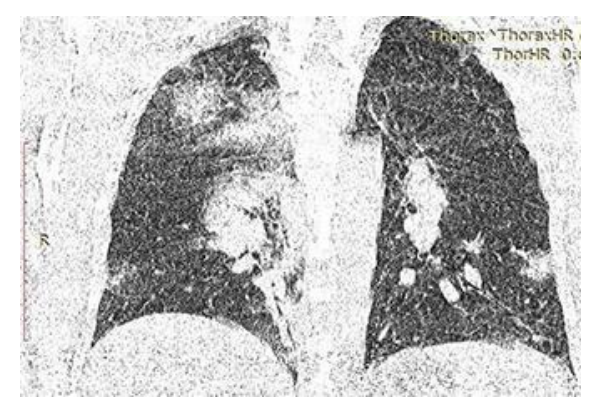

Fig. 1. CT of the chest, axial view, shows bilateral peripheral ground-glass pulmonary opacities associated with interlobar septal thickening. 
Case Reports in Neurology
Case Rep Neurol 2021;13:398-404

DOI: $10.1159 / 000513977$

(c) 2021 The Author(s). Published by S. Karger AG, Basel www.karger.com/crn

Hassoun et al.: COVID-19 and Acute Myelopathy

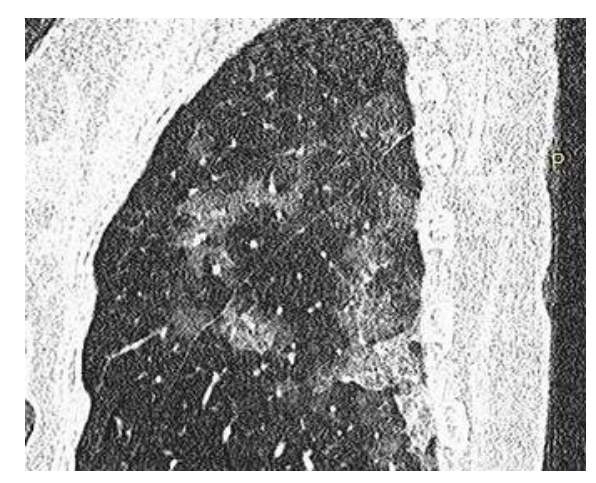

Fig. 2. CT of the chest, coronal view, shows multiple peripheral ground-glass pulmonary opacities with fine reticulation.

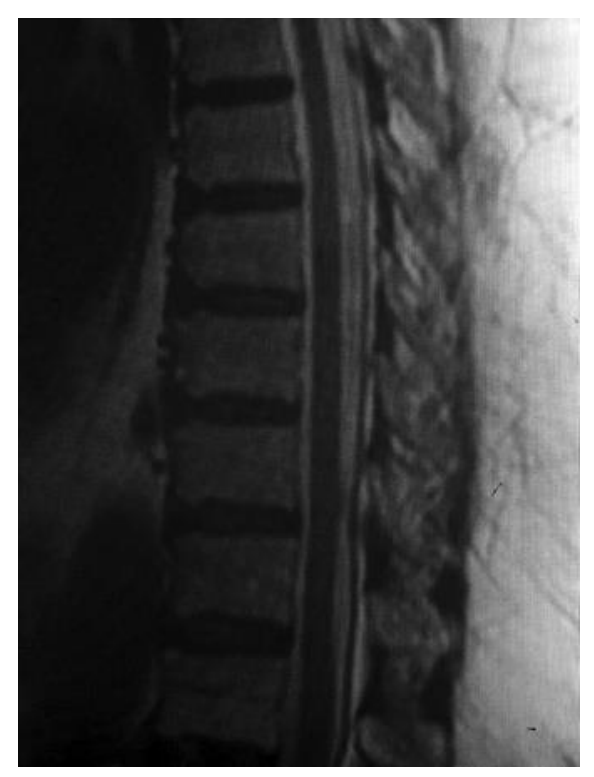

Fig. 3. Sagittal MRI T2WI shows mild degenerative changes and normal dorsal cord intensity.

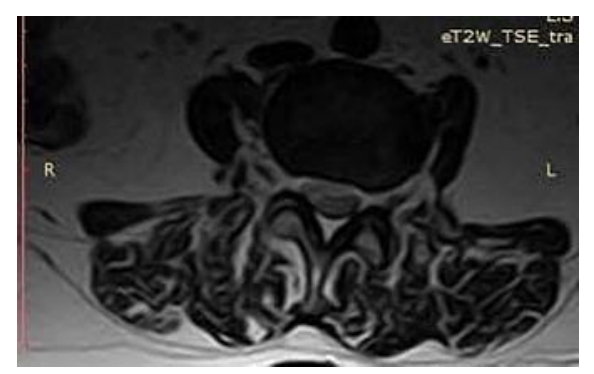

Fig. 4. MRI T2 axial section shows mild degenerative spondylotic changes in the form of thickening ligamentum flavum and facet joint degeneration.

\section{Karger'}


Case Reports in Neurology
Case Rep Neurol 2021;13:398-404

DOI: $10.1159 / 000513977$

(c) 2021 The Author(s). Published by S. Karger AG, Basel www.karger.com/crn

Hassoun et al.: COVID-19 and Acute Myelopathy

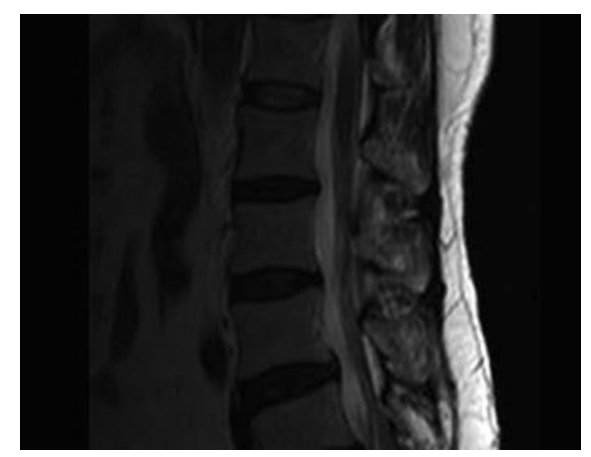

Fig. 5. MRI T2 sagittal section shows lumbar intervertebral disc dehydration, mild posterior bulge, no significant canal stenosis with normal conus. 